\title{
Bilateral ve tekrarlayan fasiyal paralizinin nadir nedeni: Melkersson-Rosenthal sendromu
}

\author{
A rare cause of bilateral and recurrent facial palsy: Melkersson-Rosenthal sendromu
}

\author{
Mehmet Akdağ, Fazıl Emre Özkurt, Beyhan Yılmaz, İsmail Topçu, Faruk Meriç
}

\section{ÖZET}

Melkersson-Rosenthal Sendromu yineleyen periferik fasiyal paralizi, orofasiyal ödem ve fissürlü dil triadı ile karakterize granülomatöz hastalıktır. Bu yazımızda çocukluktan itibaren 2 kez sol ve bir kez sağ taraftan periferik paralizi atağı geçiren ve idiopatik fasiyal paralizi tanısı alan olgunın kliniğimize tekrar sağ tarafta periferik fasiyal paralizi ön tanısı ile yatırılıp tetkik ve takip sonucunda Melkersson-Rosenthal Sendromu (MRS) tanısı alan hastada; fasiyal paralizinin farklı tarafta ve farklı zamanlarda tekrarlayıcı olması ve tedaviye dirençli olması ve ayrıca gençlik çağında ender görülüyor olması nedeniyle sunulmuştur. Ancak bu sendromla ilgili gerek doğru etiyoloji ve gerekse sonuç veren tedavi açısından klinikopatolojik ek çalışmalara intiyaç duyulmaktadır.

Anahtar kelimeler: Melkersson-rosenthal sendromu, fasiyal paralizi, fissürlü dil

\section{GíRiș}

Melkersson-Rosenthal Sendromu (MRS) yineleyen periferik fasiyal paralizi, orofasiyal ödem ve fissürlü dil triadı ile karakterize granülomatöz hastalıktır. Yaşamın 2 veya 3. dekatında görülebilen nadir rastlanılan ve nedeni kesin bilinmeyen bir hastalıktır [1]. Yaşamın gençlik çağında ender görülmesine karşın bu sendroma yaşamın 2. ve 3. dekatında daha sık rastlanır. MRS; ender görülen bir hastalık olup, insidans $1 \% 0,08$ olarak bildirilmektedir [2]. Hastal1ğın etiyolojisi tam olarak bilinmemekle birlikte, etiyopatogenezde ailevi eğilim, infeksiyonlar, genetik faktörler, immün yetmezlik, atopi, besin intolerans1

\begin{abstract}
Melkersson-Rosenthal syndrome is a granulomatous disease which is characterized by the triad of recurrent peripheral facial palsy, orofacial edema, and fissured tongue. In this article we presented one case who, since childhood, had had peripheral paralysis attack twice on the left side and once in the right side and was diagnosed with idiopathic paralysis before being admitted to our clinic for the second time with the preliminary diagnosis of peripheral facial paralysis on the right side and then diagnosed and followed up with the diagnosis of Melkersson-Rosenthal Syndrome (MRS). We presented this case since the facial paralysis recurred on the different side and in different times and also since it remained resistant to treatment of steroids and it is seen rarely in adolescence. However, further clinic-pathological studies are required to investigate the etiology and find right treatment procedures for this syndrome.
\end{abstract}

Key words: Melkersson-Rosenthal syndrome, facial paralysis, fissured tongue

ve stres faktörleri gibi birçok etken suçlanmaktadır [3-5].

Sendromun belirti ve bulgularının spontan veya medikal tedaviyle gerilediğine dair yaygın kanı olmasına karşın, bazı hastalarda klinik progresif seyredebilmekte ve cerrahi tedavi (fasiyal sinir dekompresyonu) gerektirmektedir.

Bu yazımızda çocukluktan itibaren 2 kez sol ve bir kez sağ taraftan periferik paralizi atağ 1 geçiren ve idiopatik fasiyal paralizi tanısı alan olgunun kliniğimize tekrar sağ tarafta periferik fasiyal paralizi ön tanısı ile yatırılıp tetkik ve takip sonucunda Melkersson-Rosenthal Sendromu (MRS) tanısı alan 
hastada; fasiyal paralizinin farklı tarafta ve farklı zamanlarda tekrarlayıcı olması ve tedaviye cevap alınamaması ve ayrıca gençlik çağında ender görülüyor olması nedeniyle vaka sunulmuştur.

\section{OLGU SUNUMU}

Dicle Üniversitesi Tıp Fakültesi Kulak Burun Boğaz kliniğine 21 yaşında erkek hasta yaklaşı 6 ay önce 10 gündür gözünü kapatamama, ağız köşesinin sağ tarafa kayması, ve gözlerinde yaşarma şikayeti ile sağ fasiyal paralizi ön tanısı nedeniyle tetkik ve tedavi amaçlı yatırıldı. Hastanın muayenesinde; sağ gözünü kapatamama, dişlerini s1karken sağ nazolabial sulkusta düzleşme, gözlerinde yaşarma ve çene kaslarında dikkatli gözlemle farkedilen kas seyirmesi tespit edildi (Resim 1).Ayrıca fasiyal paralizi bulguları dişında yapılan kulak burun boğaz muayenesinde sağ yanakta hafif şişlik, dilde fissürlü yapının (Resim 2) fark edilmesi diğer önemli muayene bulguları olup; kulak zarları bilateral sağlam idi. Anamnezde daha önce sağ tarafta bir kez ve sol tarafta iki kez olmak üzere yüz felci geçirdiğini ifade etmesi üzerine muhtemel etiyolojiyi saptamak üzere önce kontrastlı internal akustik ve kranial manyetik rezonans (MR) çektirildi. MR'da şüpheli sol anterior inferior kranial arter internal akustik düzeyinde tip 1 lup oluşturan ve 7. Sinir ile yakınlık imajı oluşturmakla beraber serebello-pontin köşe ve internal akustik kanal normal görünümde idi (Resim 3). Ayrıca 0.5-1mm kesitlerle çekilen temporal kemik tomografisinde mastoit ve orta kulak havalanmas doğal olup internal akustik kanalda belirgin asimetri gibi belirgin patoloji gözlenmedi (Resim 4). Odyolojik tetkikte hastada normal pure tone skorları elde edilmekle beraber stapes refleksi sağ tarafta tüm frekanslarda elde edilemedi. Hastanın ilk gün yatışında prognozu takip ve tedaviye cevap vermek için kullandığımız House Brackmann Skalası 4 idi. Yapılan elektromyografide yüzün istemli kaslarında Motor Unit Potansiyel (MUP) aktivitesi elde edilemedi; istirahatte fasikilasyon ve fibrilasyon aktivitesi izlenerek fasiyal sinirin denervasyonu ile uyumlu sonuç alındı. Hastanın steroit ve anti viral ilaç dahil olmak üzere 14 günlük medikal tedavi ve aynı anda fizik tedavi rehabilitasyonu uygulanmasına rağmen House Brackmann Skalasında değişiklik olmadi. Ancak hasta yaklaşık 6 ay boyunca ayda bir olmak üzere takip edilmek kaydı ile taburcu edildi. Takip döneminde yirmi bir gün boyunca sabah kahvaltı önce- si bir adet Pantoprazol 20 mg ve kullanılan steroid tedavisinin sonlandırıldığı son doz olan $4 \mathrm{mg}$ metil prednisolon günde bir kez tok karınla devam edildi. Daha sonra fizik tedavi ve rehabilitasyon kliniği tarafından önerilen eksersizleri hasta tarafından düzenli olarak yapıldı. Fasiyal paralizi takibi açısından kontrol tarihinden önce polikliniğimize başvuran hastanın tam olmamakla beraber gözünü kapatmaya başladığını ve yüzünde his duyusunun tekrar geldiğini ifade eden hastanın muayenesinde House Brackmann Skalasının 3'e gerilediğini ve paralizinin kısmen gerilediğini tespit ettik (Resim 5) ve otoloji -nöroloji konseyi önerisi ile hasta takibine devam kararı alınd1.

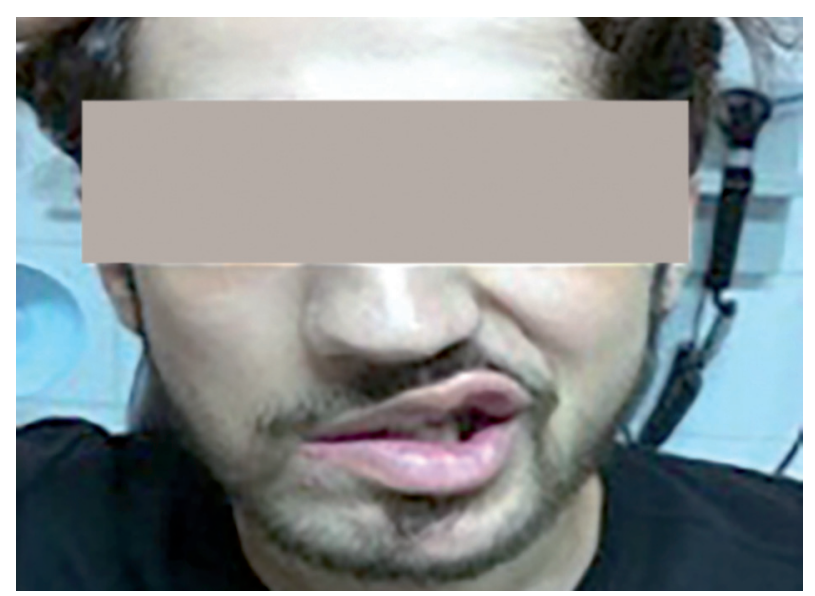

Resim 1. Hastanın tedavi öncesi hastaneye başvuru öncesi fasiyal paralizili hali

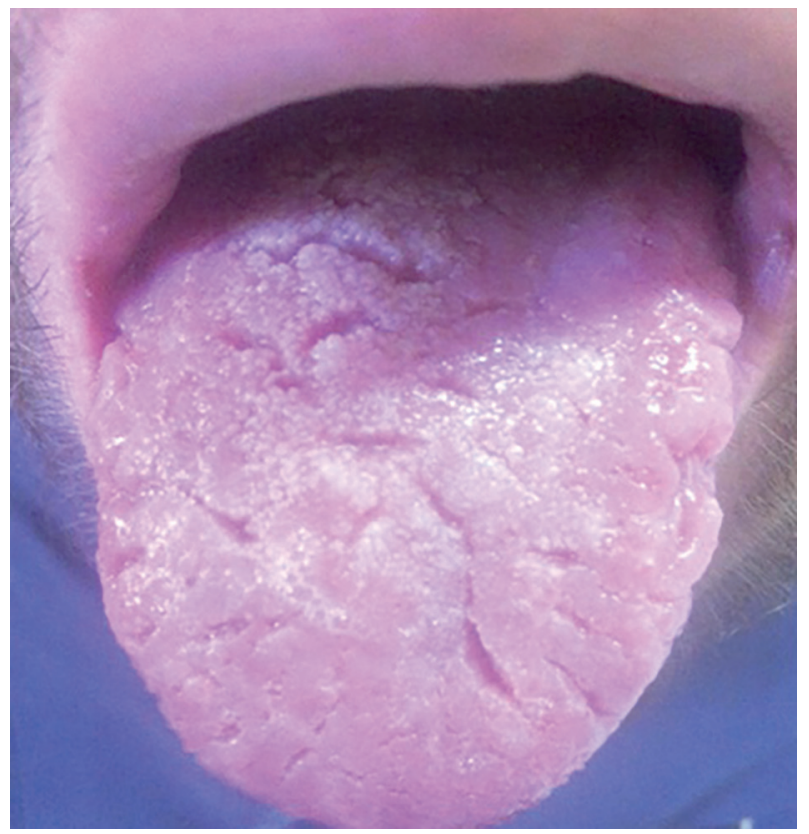

Resim 2. Hastanın fissürlü dil görünümü 


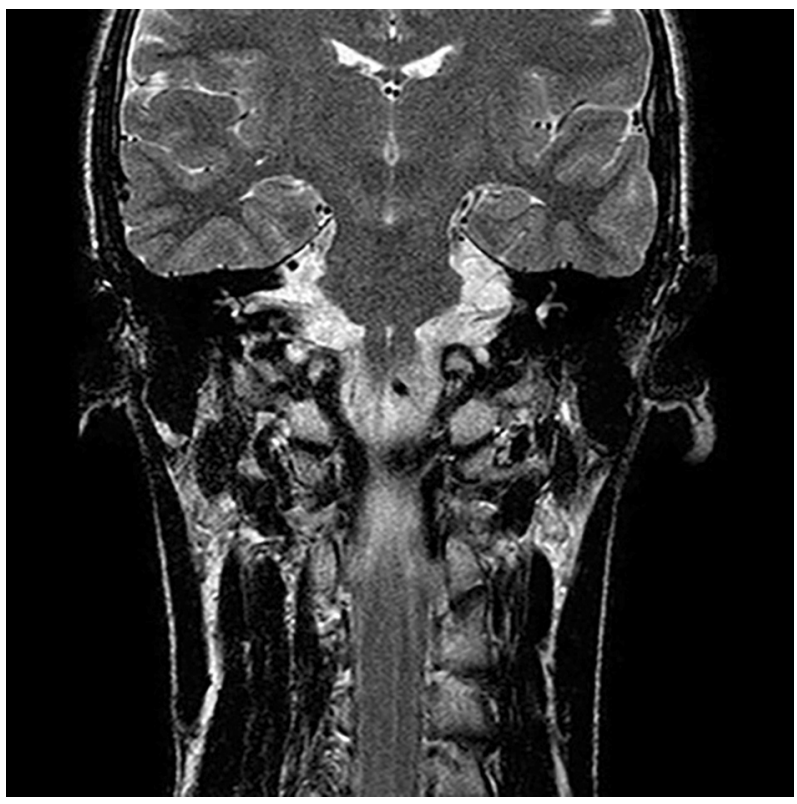

Resim 3. Kontrastlı Kranial ve internal akustik kanal manyetik rezonans görünümünde solda anterior inferior kranial arter ile fasiyal sinir yakınlığı dışında normal görünüm

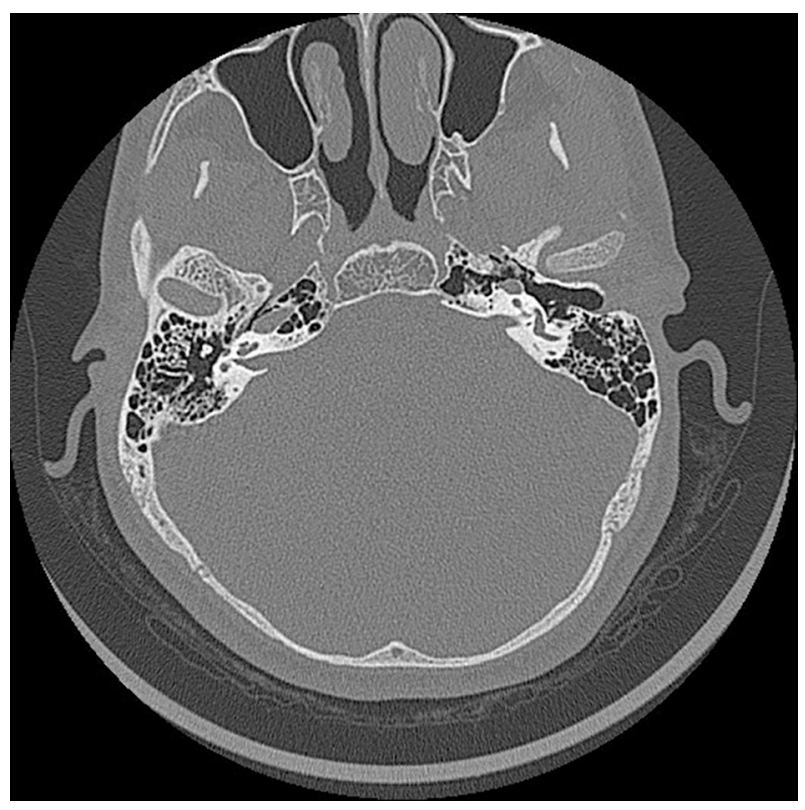

Resim 4. Temporal kemik tomografisinde havalanan mastoid ve orta kulak görünümü ile beraber simetrik internal akustik kanal

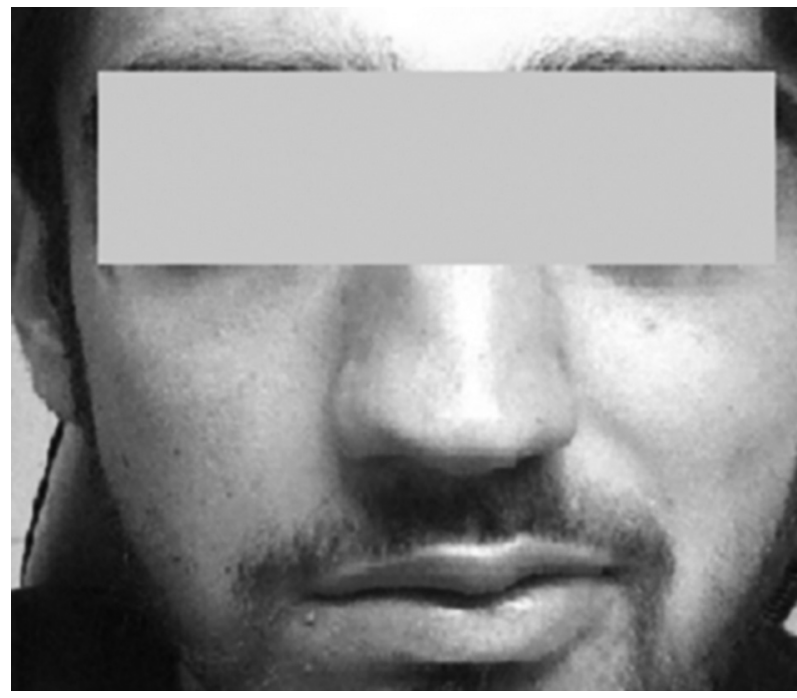

Resim 5. Medikal tedavi sonrası önceki duruma göre göz kapatmasının minimal arttığı fasiyal paralizili hali

\section{TARTIŞMA}

Fasiyal paralizi nedenleri, klinik gidişat ve cerrahi planlama zamanı gerek kulak burun boğaz pratiğinde tartış1lan ve gerekse oto-nöroloji alanında hala tartışılan konulardan biridir.

MRS'nun etiyolojisi tam olarak bilinmemekle birlikte bakteriyel ve viral infeksiyonlar; özellikle herpes simpleks infeksiyonu, atopi ve bazı besin katk1 maddelerine ve ağır metallere karşı gecikmiş hipersensitivite, stres, otoimmün ve genetik faktörler suçlanmaktadır [1,2 6,7]. Ancak hastamızda gerek anamnez ve gerekse yatış esnasında nöroloji ve dahiliye konsültasyonları sonucunda belirgin etiyolojik neden gözlenmedi.

MRS tekrarlayan periferik fasiyal paralizi, orofasiyal şişlik (ödem) ve fissürlü dil triadı gibi klinik bulgularla ile karakterize nöro-mukokütan granülomatöz bir hastalık [1,2] olarak tarif edilmesine karşın kesin tanı histopatolojik bulgular-biyopside non-kazeöz granülomatöz keilitis varlığı- tanıyı desteklenir [8]. Ancak gerek hasta onay1 gerekse patolojik sonuç olmaması tanıyı desteklemese de hastalığ 1 ekarte ettirmez [9]. 
Tekrarlayan periferik fasyal paralizi nedenleri ara $\neg$ sinda Bell paralizisi, Melkersson-Rosenthal sendromu (MRS), enfeksiyöz mononükleozis, sifiliz, herpes zoster, otitis media, multiple skleroz, diyabetes mellitus, lösemi, myastenia gravis, Guillain-Barre sendromu, poliarteritis nodoza ve tümörler akla gelmelidir [2]. Bu hastalıklar arasında ayırıcı tanıya varmak için fasiyal paralizi dışında muhtemel nedenleri ve olmasi ihtimali olan sendrom tan1s1 için hem sistemik hem de tam kulak burun boğaz muayenesi gerekli olduğunu düşünüyoruz. Nitekim bizim vakamızda fasiyal paralizi dışında dil yapısının fissürlü olması ve sağ yanakta zor fark edilebilen şişlik olması bize MRS tanısını hatırlattı.

Yine MRS 'de \%47 ile \%90 oranında fasiyal paralizi görülüp bu durum genelde tek taraflı olup klinik olarak Bell paralizisine benzemekle beraber fasiyal paralizinin bilateral veya karşı tarafta olabileceği de bildirilmektedir [10]. Burada görülen fasiyal paralizinin fizyopatolojisinin muhtemelen fasiyal sinir dokusunun non-kazeöz granülomatöz infitrasyonuna veya ödem basisına bağlı olarak geliştiği düşünülmektedir [1].

MRS'de orofasiyal ödem en s1k görülen bulgu olup, olguların \%80 ile \%100'ünde mevcuttur [1]. Orofasiyal ödem fasiyal paraliziden önce gelişebilir. Genellikle tek taraflı ve ağrısızdır. Diffüz veya nodüler olabilir. Siklıkla üst dudakta yerleştiği gibi alt dudak ve yanaklarda da olabilir. Daha ender olarak göz kapağı, alın veya kafa derisinde de bulunabilir. Yinelemeler sonucu fibrosis ve yumuşak doku hiperplazisi geliştiğinde kalıcı olabilir [11]. Fissürlü dil sağlıklı popülasyonda doğuştan bulunabildiği için ve MRS'de \%940 oranında görüldüğünden hastalık için spesifik değildir $[1,11]$. Hastamızda da MRS'nda en s1k bulgu olan orofasiyal ödemin periferik fasiyal paraliziye eşlik etmekle beraber belirgin değildi.

Hastanın sol internal akustik kanaldaki sinir damar yakınlığ 1 Cros Compression sendromunundan şüphelendirmekle beraber hasta kliniğinin bilateral olması bizi tanıdan uzaklaştırmış ve mevcut görüntü izole anatomik varyasyon olarak değerlendirilmiştir.

Fasiyal paralizilerin prognostik tetkikleri içerisinde yer alan ve hastanemizde bulanan elektromyografide yüzün istemli kaslarında MUP aktivitesi elde edilememesi ve istirahatte fasikilasyon ve fibrilasyon aktivitesi izlenerek fasiyal sinirin denervasyonu ile uyumlu sonuç alınması iyileşmenin geç olmasını bize doğru olarak göstermişti.

Tedavide kortikosteroidlerin ödemi ve doku zedelenmesini önlediği bildirilmiştir. Lezyon içi glukokortikoid uygulaması sistemik glukokortikoid tedavisi kadar etkin bulunmuştur [1,12]. Ayrıca klofazimine, minoksilin, methotrexate, danazol, dapson, sulfasalazin, hidroklorokin, difenhidramin, penisilin, tetrasiklin, eritromisin ve klindamisin gibi ilaçlar da denenmiştir. Ancak biz daha çok fasiyal paralizide anti ödem ve anti-inflamatuar etkisinden yararlanmak üzere steroid tedavisini kullandık. Medikal tedaviye yanıt vermeyen olgularda fasiyal sinir dekompresyonu uygulanabilmekle beraber [13] bu müdahelenin; hastanın paralizisini kesin tedavi edemeyeceği ön bilgisi verilerek ve ayrıca hastanın kliniğinin bilateral tekrarlayan fasiyal paralizi olduğu için önerilmedi. MRS'de hamilelik veya diğer muhtemelen otoimmun gibi kesin nedenleri bilinmeyen hastalıklarda görülen fasiyal paralizi gibi tedavi ile iyileşme geç de olsa cevap alınabilinir [14].

Sonuç olarak nadir görülen bu fasiyal paralizinin gençlik yaş grubunda görülmesi, dil ve yüz muayenesi ile triadın saptanması ile beraber özellikle bilateral, tekrarlayıcı olması ve tedaviye geç cevap vermesi açısından Melkersson-Rosenthal Sendromu açısından dikkatli takip edilmesi gerektiğini önermemizle beraber sendromla ilgili gerek etyoloji ve gerekse tedavi açısından klinikopatolojik ek çalışmalara ihtiyaç duyulmaktadır.

Not: Hastadan resim kullanımı için imzalı onay1 alınmıştır.

\section{KAYNAKLAR}

1. Zimmer WM, Rogers RS, Reeve CM, et al. Orofacial manifestations of Melkersson-Rosenthal syndrome. A study of 42 patients and review of 220 cases from the literature. Oral Surg Oral Med Oral Pathol 1992;74: 610-619.

2. Ziem PE, Pfrommer C, Goerdt S, et al. Melkersson-Rosenthal syndrome in childhood: a challenge in differential diagnosis and treatment. Br J Dermatol 2000; 143:860-863.

3. Armstrong DK, Burrows D. Orofacial granulomatosis. Int J Dermatol 1995;34:830-833.

4. Worsaae N, Christensen KC, Schiodt M, et al. MRS and cheilitis granulomatosa. A clinicopathological study of thirty three patients with special reference to their oral lesions Oral Surg Oral Med Oral Pathol 1982;54:404-413. 
5. Greene RM, Rogers RS. MRS: a review of 36 patients. J Am Acad Dermatol 1989;21:1263-1270.

6. Cockerham KP, Hidayat AA, Cockerham GC, et al. Melkersson-Rosenthal syndrome: new clinicopathologic findings in 4 cases. Arch Ophthalmol 2000;118:227-232.

7. Wong GA, Shear NH. Melkersson-Rosenthal syndrome associated with allergic contact dermatitis from octyl and dodecyl gallates. Contact Dermatitis 2003;49:266-267.

8. Camacho-Alonso F, Bermejo-Fenoll A, Lopez-Jornet P. Miescher's cheilitis granulomatosa. A presentation of five cases. Med Oral Patol Oral Cir Buccal 2004;9:427-429.

9. Rogers RS 3rd. Melkersson-Rosenthal syndrome and orofacial granulomatosis. Dermatol Clin 1996;14:371-379.
10. May M, Klein SR. Differrential diagnosis of facial nerve palsy. Otolaryngol Clin North Am 1991;24:613-645.

11. Cockerham KP, Hidayat AA, Cockerham GC, et al. Melkersson-Rosenthal syndrome: new clinicopathologic findings in 4 cases. Arch Ophthalmol 2000;118:227-232.

12. Perez-Calderon R, Gonzalo-Garijo MA, Chaves A, et al. Cheilitis granulomatosa of Melkersson-Rosenthal syndrome: treatment with intralesional corticosteroid injections. Allergol Immunopathol 2004;32:36-38.

13. Kruse-Losler B, Presser D, Metze D, et al. Surgical treatment of persistent macrocheilia in patients with Melkersson-Rosenthal syndrome and cheilitis granulomatosa. Arch Dermatol 2005; 141:1085-1091.

14. Özdemir HH, Demir CF, M. Berilgen S, ve ark. Gebelik ve fasiyal dipleji: Nadir bir olgu. Dicle Med J 2012;39:419-421. 